\section{Hei, meitä huiputetaan! Eli miten kaikista tehdään huippuja}

Karin Filander, Maija Korhonen \& Päivi Siivonen (toim.) (2019). Huiputuksen moraalijärjestys. Osallisuuden ja sosiaalisen kivun kertomuksia. Vastapaino 2019. 429 sivua.

HUIPUTUKSEN moraalijärjestys on järjestyksessään 53. Aikuiskasvatuksen vuosikirja ja toinen, jonka julkaisee laadukkaista tietokirjoista tunnettu kustantaja Vastapaino. Ilman systemaattista analyysia voisin arvioida vuosikirjojen tason nousseen jatkuvasti. Tuorein edustaa huippua, ja on hyvä pari edelliselle Koko elämä töihin: koulutus tietokykykapitalismissa (Vastapaino 2015), jossa tarkasteltiin inhimillisten kykyjen muuttumista yhä enemmän kauppatavaraksi.

Artikkelikokoelmassa tarkastellaan eri näkökulmista ja eri kohderyhmissä tehdyillä tutkimuksilla markkinaliberalistisen kilpailuyhteiskunnan "huippuideologian" seurauksia eri asemissa olevien ihmisten elämässä. Seuraukset ovat yhtä hyvin taloudellisia, sosiaalisia ja terveydellisiä kuin fyysisiä ja mentaalisia. Kirjapari on kasvatustiedettä ja varsinkin aikuiskasvatusta opiskeleville välttämätöntä luettavaa ja auttaa hahmottamaan yksilön asemaa vaatimusten ja vaikutusyritysten voimakentässä.

Huiputuksen moraalijärjestys koostuu 19 tutkijan 15 luvusta, jotka on ryhmitelty neljään temaattiseen osaan. Ensimmäinen osa käsittelee ajan henkeä ja nykyisen työelämän moraalin perustaa. Alun neljä lukua jäsentävät tematiikkaa hyvin myös teoreettisesti ja käyvät johdatuksesta aiheen teoreettiseen keskusteluun ja laajempiin yhteiskunnallisiin yhteyksiin. 21. vuosisadan alun työelämää vaatimuksineen on jäsennetty lukuisilla käsitteillä, kuten 'itsen brändääminen', 'yksilön resilienssi ja kimmoisuus', 'työllistettävyys', 'tohkeisuus', 'julma optimismi', 'neuroottinen kansalaisuus'.

Käsitteiden takana purskahtelee paine itsen muokkaamiseen aikuisen ihmisen kasvattamiseen!

Karin Filanderin, Maija Korhosen ja Päivi Siivosen kirjoittama johdantoluku hyödyntää muun muassa Michelle Foucault'n, Nikolas Rosen ja Peter Millerin teoretisointeja ja analyyseja vapauden ja hallinnan yhteydestä. Huiputus ja huippupuhe ovat hallinnan keinoja, joilla yksilöt organisoidaan kilpailemaan keskenään ja motivoidaan sisäistämään "huiputtajien" ajatustavat, arvostukset ja asenteet. Tehokkaimmillaan kuuliaisten ruumiiden hallinta on perustuessaan uskomusten hallintaan.

\section{YLIOPISTOTYÖN ILOT JA KIROT}

Ensimmäisen osan kolme lukua perustuvat yliopistokontekstissa

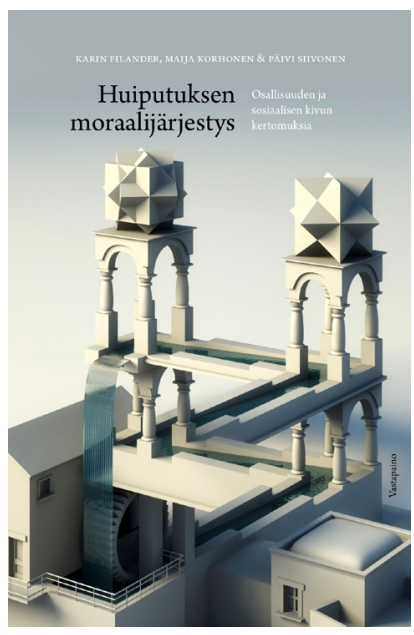

kerättyihin aineistoihin, mutta havainnot eivät rajaudu vain yliopistomaailmaan. Valtaosa kirjoittajista tekee työtään yliopistossa, ja he ovat itse kokeneet korkeakoulupolitiikan omaksuman huippuideologian rationaliteetteineen ja käytäntöineen.

Kirja ei kuitenkaan koostu vain kurjuuden kertomuksista, vaan tutkimuksen kohteena olevat huippuyliopiston huippututkijat pääsevät omien kokemustensa perusteella todistamaan asemansa suomaa vapautta ja onnea. Esimerkiksi Aalto-yliopiston nuoret tutkijat taas osaavat jo nähdä huiputuspuheen läpi ja hakevat merkitystä enemmän työnsä sisällöstä kuin kilpailusijoituksista.

Leena Koski lukee tutkimuksessaan Helsingin yliopiston ja Itä-Suomen yliopiston strategia-asiakirjoja moraalisen järjestyksen esityksinä. Hänen havaintonsa ja tulkintansa ovat antoisaa luettavaa kaikille yliopistoissa työskenteleville - ja 
opiskelijoillekin. Yliopistolaitoksen uuteen loistoon tähtäävissä strategioissa yksilön kelvollisuus arvioidaan rahanhankintakyvyn perusteella. Raha ja huippu ovat yhtä. Kaikkein parasta on kilpailtu raha. Huippuuden voi päätellä suoraan kilpaillun rahan määrästä. Se on totuus, jota ei voi kyseenalaistaa.

Raha on teknologia, joka määrittää yksilön ja yksikön arvon, eikä tieteellinen arvo eroa siitä arvosta. Yliopistojen hallinnon omaksuma uuskieli tähtää sielujen hallintaan ja yliopistojen tehtävien kehystämiseen uudella tavalla: ymmärryksen muokkaamiseen siitä, mitä me olemme tekemässä ja miksi.

Hämmästyttävintä onkin, miten yliopistojen johto ja hallinto ovat omaksuneet konsulttien puhetavat uudissanoineen ja höpöpuheineen. Suomessa Tampereen yliopiston hallinnosta on tullut huuhaan huiputtama karikatyyri korkeimman opetuksen ja tieteen kentälle. Toivottavasti hölmöily ei ole saanut tahrattua yliopiston opetus- ja tutkimushenkilökunnan uskottavuutta vakavasti otettavana tiedeyhteisönä.

Miksi yliopisto haluaa omaksua markkinamaailmasta lapsellisimmat puhetavat? Miksi se ei luota omaan järkeen, vai pelätäänkö yliopistoissa, että omaa järkeä ei ole? Tai ettei yliopistossa varjeltu tieteellinen järki kelpaa markkinoille siis? Olisi reilumpaa laittaa lappu yliopiston luukulle kuin alkaa kilpailla huippukonsulttien ja markkinagurujen kanssa liirumlaarumissa.
HUIPUTTAJAT JA HUIPUTETTAVAT

Kirjan nimessä esiintyvä 'huiputus' on kaksimerkityksinen. Kun "eliittijoukkoja" korostavalla ideologialla yritetään luoda huippuyksilöitä tai -yksiköitä, esimerkiksi huippuyliopistoja, sillä koetetaan huiputtaa. Huiputuksen mekanismi on kilpailu, jolla motivoidaan yksilöitä, oppilaitoksia ja niiden yksiköitä osallistumaan kilpailuun tehostamalla toimintaansa ja tuottamalla vielä enemmän ja vielä parempaa - aiempaa edullisemmin. Kun politiikan tähtäimessä on huippujen synnyttäminen, kilpailijoiden suuri keskinkertaisten joukko ei politiikan tekijöitä kiinnosta.

Huiputuksen toinen puoli onkin se, että kilpailuun mukaan "huiputetut" osoittavat osallistumalla, etteivät yllä huipulle ja voittajien joukkoon. Samoin huiputtava koulutuspolitiikka hyödyttää voittajia, mutta kiristää kaikkien vaatimuksia ja työtahtia, ja hermoja.

Useissa kirjan tutkimuksissa aineistoa analysoidaan kulttuurisen mallitarinan avulla. Niin haastattelu- kuin lehtitekstiainestoistakin on analysoitu, millaista ihmisihannetta niissä rakennetaan, miten vaatimukset koetaan, miten itseä muokataan, miten "haasteisiin" vastataan, millaisia hyveitä vaaditaan, millaiset uhat menestystä uhkaavat, ja millaista järjestystä elämään ja yhteiskuntaan ylipäätään luodaan.

Esimerkiksi Erja Laakkonen analysoi naistenlehtien henkilöjutuista, mitä tekstit kertovat muu- toksen tekijää odottavasta "hyvästä elämästä” sekä muutoksen tekijän hyveistä, ideaaliminästä. Millaisia ominaisuuksia yksilöllä tulee olla hyvän elämän saavuttamiseksi? Miten teksteissä näkyy uusliberalistinen yksilökeskeinen eetos, joka kannustaa oman elämän projektinomaiseen rakenteluun ja yksilöllisiksi koettuihin valintoihin? Näitäkin tekstejä voi lukea aikuiskasvatuksena. Naistenlehtien lukijat, kuten medioiden kuluttajat yleensä, reflektoivat lukemaansa suhteessa omaan elämäänsä. Samoin positiivinen psykologia ja self help -kirjallisuus on suostuttelua, ellei peräti peitelty käsky itsen muokkaamiseen olosuhteista piittaamatta, kuten Antti Saari kirjoittaa.

\section{KOHTUULLISUUTTA KAIVATAAN}

Monet kirjaan haastatelluista ja kirjoittajista päätyvät implisiittisesti tai eksplisiittisesti toivomaan kohtuullisuutta huiputuksen sijaan - sitä, että niin työelämässä kuin yleisemminkin yhteiskunnassa hyväksytyksi toiminnaksi riittäisi omaan jaksamiseen sovitettu työpanos. Nykyisten johtamisoppien mukainen moraalijärjestys vaatii itse kutakin omaksumaan kilpailullisuuden elämänasenteeksi. Siitä on tehty hyve, mallikansalaista liikuttava ominaisuus.

Kirjaan haastatellut todistavat vahvasti, ettei yksilöiden keskinäiseen vertailuun ja kilpailuun osallistuminen kiinnostaisi heitä lainkaan. Kilpailuhalu on pikemminkin ulkoapäin pakotettu käytäntö, jota vastaan on yksin lähes mahdotonta asettua. 


\section{MONI TOIVOO, ETT ̈̈ HYVÄKSYTYKSI TOIMINNAKSI}

\section{RIITT ÄISI OMAAN JAKSAMISEEN SOVITETTU TYÖPANOS.}

Eeva Jokinen erittelee kiinnostavasti toimijuuden ehtoja ja eriasteisia toimijuuksia prekaarissa työelämässä. Toimijuuden rajat ovat ympäröivissä rakenteissa. Samalla rakenteet tekevät toimijuuden mahdolliseksi, kuten monet sosiologiat ovat teoretisoineet. Toimijuutta ei kuitenkaan tule ymmärtää olettamalla toimija suvereeniksi: "Toimijuudesta tulee tässä päättelyssä helposti valintoja, elämäntapavalintoja, kulutusvalintoja ja erilaisia 'neuvotteluja', ja vähäinen, huomaamaton tai 'mutiseva' toimijuus jää tarkastelun ulkopuolelle." Empiirisesti tarkastellen monissa tilanteissa ja oloissa toimijuus on pikemmin hengissä pysyttelemistä kuin suvereenia tavoitteellista toimintaa. (s. 81.)

Kohtuullistamisellakin voi olla rajansa, koska talousjärjestelmä hyödyntää tehokkaasti ihmisten muuttuvat toiminta- ja ajattelutavat. Huiputuksen vastustamisen ja kohtuullistamisen käytännöt koetetaan saada jossain vaiheessa osaksi tuotantoa ja palvelemaan huiputusta: "Käynnissä oleva muutos materiaalisesta, fordistisesta tuotannosta tietokykykapitalismin suuntaan ottaa affektit ja kaikki mahdolliset tuntemukset, aavistukset ja etiäiset osaksi arvonmuodostusprosessia. Ihmisen jokainen teko tai tekemättömyys on mahdollisesti osa tuotantoa." (s. 94.)

\section{SOSIAALISEN KIVUN RAKENTEET}

Kirjan poleemisuus juontuu siitä, että siinä on lähdetty analysoimaan kokemuksia, joita syntyy, kun huiputuksen politiikan ja psykokapitalismin vaatimukset "tärähtävät yksilöön”, työntekijään, kansalaiseen. Kirja on näkemyksellinen. Kirjoittajat suhtautuvat kaikkialle leviävään huiputukseen kriittisesti ja sanovat kirjan lähteneen liikkeelle "pyrkimyksestä vastustaa 'huiputusta' ajan henkenä, joka samanaikaisesti kutsuu mukaansa ja kuristaa ihmisiä monin tavoin." (s. 8.)

Kirjan alaotsikko "Osallisuuden ja sosiaalisen kivun kokemuksia" kertoo kritiikin peruslähtökohdan ja kirjan näkökulman: huiputuksessa joku tai jotkut voittavat, mutta - kuten kaikessa kilpailussa - keskinkertaisiksi ja häviäjiksi leimattujen joukko muodostaa suuren enemmistön. Mount Everestissäkin kiinnostaa se korkein huippu ja sinne päässeet, mutta huippu ei olisi olemassa ilman valtavaa kivimassaa sen alla.

Sosiaalinen kipu on vääjäämätön seuraus kilpailun rakenteesta. Riittämättömyyden tunnetta ja kelvottomuuden leimaa voi koettaa paeta vain uhraamalla jatkuvasti enemmän itseään kilpailuksi organisoidulle tuottamiselle. Mikäli kelvottomuuttaan kuitenkin oppii sietämään, työelämän kilpailusta voi astua syrjään ja koettaa tyytyä siihen, että tekee asiat kohtuullisesti ja riittävän hyvin.

Mutta potkuthan sellaisesta kohtuullistamisesta lopulta tulee.

\section{YHDISTY JA VASTUSTA!}

Muutamissa luvuissa koetetaan hakea vaihtoehtoisia tapoja pärjätä nykyisessä työelämässä erittelemällä kyynistymistä, luovuttamista ja oravanpyörästä pois hyppäämistä, työn omakohtaista tuunaamista ja tilan valtaamista työpaikoilla. Elina Henttonen ja Kirsi LaPointe nostavat esiin yksilöllisten ratkaisujen lisäksi joukkovoimaksi koordinoidun yhdessä tekemisen. Juuri sille tullee olemaan tilausta tulevaisuudessa, uskoisin.

Managerialistinen johtamiskulttuuri nojaa pitkälti yksilöllistävään kaikkien kilpailuun kaikkia vastaan. Tätä hajottamisen ja hallitsemisen trendiä lienee paras vastustaa yhdistymällä.

\section{HEIKKI SILVENNOINEN}

professori

kasvatustieteiden laitos,

Elinikäisen oppimisen ja

koulutuksen tutkimuskeskus CELE

Turun yliopisto

(D) https://orcid.org/0000-00018304-0021 